\title{
Apa Itu Kewirausahaan dan Kaitannya dengan Ide Bisnis
}

\author{
Anvi Nathaniela Bunarto \\ Program Studi Kewirausahaan \\ Universitas Bina Nusantara \\ anvi.bunarto@binus.ac.id
}

Wira memiliki arti berani sedangkan usaha merupakan daya upaya. Berdasarkan arti wira dan usaha maka kewirausahaan adalah suatu sikap, jiwa, dan kemampuan untuk menciptakan sesuatu yang baru, sangat bernilai dan berguna bagi dirinya dan orang lain. Kewirausahaan juga berarti sikap mental dan jiwa yang selalu aktif atau kreatif berdaya, bercipta, berkarya, bersahaja dan berusaha dalam rangka meningkatkan pendapatan dalam kegiatan usahanya (Hastuti et al., 2020). Berdasarkan arti kewirausahaan di atas, dapat disimpulkan bahwa kewirausahaan adalah proses dalam menciptakan sesuatu yang baru seperti ide bisnis baru atau menciptakan inovasi bisnis baru atau menciptakan sesuatu yang memiliki nilai (value) bagi diri sendiri dan sesama.

Ada beberapa yang masih bingung mengenai perbedaan dari kewirausahaan, wirausahawan, dan berwirausaha. Cantillon mengatakan bahwa wirausahawan adalah seorang pengambil resiko, dengan melihat perilaku mereka yakni membeli pada harga yang tetap namun menjual dengan harga yang tidak pasti (Helmi, 2016). Sedangkan, berwirausaha merupakan suatu kegiatan usaha yang melibatkan kemampuan untuk melihat kesempatan-kesempatan usaha yang kemudian mengorganisir, mengatur, mengambil resiko, dan mengembangkan usaha yang diciptakan tersebut dengan maksud untuk meraih keuntungan (Budhiarto, 2012). Jadi, berdasarkan pengertian kewirausahaan, wirausahawan, dan berwirausaha di atas dapat disimpulkan bahwa kewirausahaan merujuk pada proses, sikap, jiwa, wirausahawan merujuk pada orang, sedangkan berwirausaha merujuk pada kegiatan berupa membangun suatu usaha.

Ada tiga tujuan kewirausahaan, yaitu 1) meningkatkan banyak pengusaha yang memiliki kualitas tinggi, 2) meningkatkan kemampuan (skill) dan daya integritas tinggi untuk para pengusaha untuk lebih meningkatkan kesejahteraan masyarakat, 3) meningkatkan dan mengembangkan kesadaran berwirausaha untuk semua golongan, mulai dari pelajar, mahasiswa, dan masyarakat lainnya (Ketaren, 2015). Pernyataan di atas dapat disimpulkan bahwa tujuan dari kewirausahaan adalah untuk menciptakan usaha baru dan meningkatkan kemampuan para pengusaha dalam hal kreatif dan inovatif.

Berdasarkan penjelasan di atas, dapat disimpulkan bahwa kewirausahaan bisa diartikan sebagai proses menciptakan atau membuat sebuah ide bisnis baru atau 
membuat inovasi bisnis baru dari bisnis yang sudah ada untuk menciptakan nilai (value) yang berguna bagi diri sendiri serta masyarakat dengan mengandalkan kreativitas dan inovatif para pengusaha yaitu orang yang membuat bisnis tersebut, founder. Melihat peluang yang ada di pasar dalam menciptakan sebuah ide bisnis merupakan hal penting dalam kewirausahaan. Setelah ide bisnis diciptakan, maka perlu ditulis rencana bisnis atau business plan supaya kita bisa tahu bagaimana peluang ide bisnis kita di pasar dan apakah ide bisnis kita bisa dipasarkan. Ada dua alasan utama yaitu internal dan eksternal ketika menulis business plan. Alasan internalnya adalah memaksa tim pendiri untuk bekerjasama dalam menyelesaikan rincian usaha bisnis. Kemudian, alasan eksternalnya adalah mengkomunikasikan manfaat usaha baru ke orang luar, seperti investor dan bankir (Barringer, 2015). Oleh karena itu, business plan termasuk hal yang penting supaya kita tahu apakah ide bisnis kita bisa dijalankan atau tidak, lalu, hambatan dan masalah apa yang mungkin terjadi, dan lain-lain.

\section{References}

Barringer, B.R. ((2015). Preparing Effective Business Plans: An Entrepreneurial Approach (2nd ed.). Pearson.

Budhiarto, Y. K. (2012). Analisis Kesesuian Karakteristik Pimpinan Restoran Pringgadding Berdasarkan Teori Geoffrey G. Meredith. 1996, 5-27. Universitas Katolik Soegijapranata. http://repository.unika.ac.id/8714/

Hastuti, P., Nurofik, A., Purnomo, A., Hasibuan, A., Aribowo, H., Faried, A. I., Tasnim, T., Sudarso, A., Soetijono, I. K., Saputra, D. H., \& Simarmata, J. (2020). Kewirausahaan dan UMKM. Yayasan Kita Menulis.

https://kitamenulis.id/2020/03/02/kewirausahaan-dan-umkm/

Helmi, A. F. (2016). Kewirausahaan di Perguruan Tinggi dalam Perspektif Psikologi.

Buletin Psikologi, 17(2), 57-65. https://doi.org/10.22146/bpsi.11484

Ketaren, N. (2015). Makalah Kewirausahaan Tanggal 13-15 November 2015

Bertempat di Hotel Sapadia Parapat pada Kegiatan Character Building \& Workshop Program Studi IImu Administrasi Bisnis. Universitas Sumatera Utara. https://repository.usu.ac.id/bitstream/handle/123456789/61267/KEWIRAUSAHAA N.pdf;sequence $=1$

\section{Biografi}

\section{Anvi Nathaniela Bunarto}

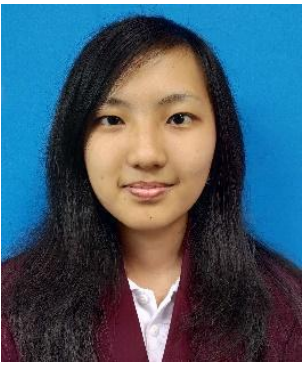

Penulis ini lahir di Malang dan merupakan seorang mahasiswa program studi kewirausahaan di Universitas Bina Nusantara, kampus Malang sejak tahun 2020. Prinsip hidup yang dimiliki oleh Anvi adalah "Apapun yang terjadi meskipun kita terjatuh sekalipun, kita harus terus bangkit dan mengejar yang kita impikan" .

Email: anvi.bunarto@binus.ac.id 